\title{
11 One sauce for the goose, another for the gander
}

\author{
Zambian women judges and \\ perceptions of illegitimacy
}

\author{
Tabeth Masengu, PhD
}

\section{Introduction}

As of late 2018, 53\% of judges in the Zambian Superior Courts were women, which is uncommon even in Scandinavian countries considered as beacons of gender equality. ${ }^{1}$ If one compares women's statistics in the three arms of government, the judiciary is an outlier on statistical terms alone. As of 2018, only $18.8 \%$ of members of parliament are women, and only $30 \%$ of cabinet ministers are women. ${ }^{2}$ A judiciary with $53 \%$ of women judges evokes suspicion, as it is considered "abnormal" in comparison to other branches of government. Consequently, there have been questions about whether these judges are deserving of their appointments. This chapter examines these questions and explores the content of this skepticism. It argues that in Zambia, current doubt regarding women judges is partially attributable to historical legitimacy perceptions. These perceptions view men as the "right" candidates for authoritative positions. This perception is worth examining, because illegitimacy perceptions of women can harm judicial governance for three reasons. Firstly, democratic values such as transparency, accountability, participation, and representativeness are essential for a court's legitimacy (Grossman, 2012). Therefore, negative views of women's roles have the potential to impede the value of representativeness, because they could dissuade judicial selectors from selecting more women judges. The reluctance to pick women judges would invariably also affect the value of participation, because equal participation of genders in decision-making bodies is a critical aspect of good governance.

Secondly, one of the justifications advanced for gender diversity is that it enhances the legitimacy of the judiciary and improves public trust in the courts (Mokgoro, 2010). Citizens are more likely to have a favorable experience with the justice system if they believe that the courts are trustworthy. However, illegitimacy perceptions can affect the legitimacy justification for gender diversity, because the legitimacy rationale for diversifying the courts is probably based more on perception than on the actual outcome (Albertyn, 2014). Therefore, negative perceptions of women have the potential to undermine the legitimacy of the judiciary and judicial governance as a whole. 
Thirdly, illegitimacy perceptions also have symbolic ramifications for the quest to diversify judiciaries. Judges have a symbolic and substantively powerful duty - that of interpreting and defending constitutional values (Arrington et al., 2017). In adjudication, the presence of women signals equality of opportunity for women not just as subjects of the law but as actors in the critical task of breathing life into constitutional values. Negative perceptions devalue the symbolic value of women judges in the constitutional project, thereby questioning the ability of women to be actors and changemakers in a time when constitutional jurisprudence is needed.

The analysis provided in this discussion draws upon 23 interviews conducted in Zambia from November 2016 to August 2018. ${ }^{3}$ The interview participants were women judges, legal professionals, members of the Judicial Service Commission (the body that selects judges), and civil society members. I triangulate these accounts by referring to the work of Alice Evans (2014, 2016), who has conducted empirical research in Zambia, and media statements by influential Zambian women on the challenges they have faced. I commence with a discussion of the judicial role in contemporary times before highlighting the status of Zambia's Superior Courts. The next section considers how women are regarded as outsiders because of historical experiences as illegitimate power holders. This chapter then makes specific reference to the situation of Zambian women in positions of power.

Consequently, the chapter outlines the criteria to be a judge in Zambia to provide context to the discussions that follow regarding skepticism in respect of women judges. Accordingly, I examine the interview responses to reveal how these perceptions of illegitimacy work and why they are invariably a result of the perceived incongruence between the ideas of womanhood and the role of a judge. I conclude by suggesting that further research on judicial performance would help negate these perceptions of illegitimacy.

\section{The judicial role in contemporary times}

The role of the judge on the African continent has taken on different meanings since the 1990s. Before this period, judges were mostly confined to criminal, civil, and labor law adjudication; now, judges adjudicate core human rights cases, public policy questions, and political controversies. These are questions of mega politics-political controversies that define the boundaries of the collective or cut through the heart of entire nations (Hirschl, 2008). Accordingly, the legitimacy of courts and the public's confidence in the role of courts to address these controversies are determined by many factors, among them the diversity of the court (Solanke, 2008). Importantly, gender-diverse courts are more likely to make better decisions, because they infuse the perspectives of different judges from different backgrounds (O'Regan, 2012). Devlin et al. have also argued that the equality argument for diversity means that there should be equal opportunities for those who apply the law, and this is absent when one group (men) dominate the adjudication of law (Devlin, MacKay, \& Kim, 2000). Article 12 of the 
Southern African Development Cooperation (SADC) Protocol on Gender and Development (SADC, 2008) and the United Nations Sustainable Development Goal (SDG) 5 both call for, among others, "women's full and effective participation and equal opportunities for leadership at all levels of decision-making" (Sustainable Development Solutions Network, 2020). The judicial role is a public decision-making role. Thus, it falls squarely under these guidelines, placing states under an obligation to ensure that more women are appointed as judicial officers.

The Commonwealth Latimer House Principles recognize the importance of gender diversity. They state that the appointment process should ensure equal opportunities for eligible persons, that appointment should be based on merit, and that attention should be given to the need for progressive attainment of gender equality (Commonwealth, 2003). The first judicial appointment guidelines issued by the Southern African Chief Justices Forum (SACJF) also identify gender as an appropriate ground on which to actively prioritize the recruitment of appointable candidates (Southern African Chief Justices Forum, 2018). Amidst these developments, it is worth remembering that the role of a judge comes with heavy responsibilities and sometimes, even expectations that judges will be superhuman. Green (2014) counters this expectation by reminding us that judges are humans who need to calculate, who need to use languages, and who need to conform to moral principles. He goes on to add that the judicial role consists of three main families of obligations: first, law-applying obligations, which include correct findings of fact and knowledge of the law and how to apply it; second, law-improving obligations, which means clarifying where necessary and resolving conflicts in law; third, law-protecting obligations, which occur when judges are regulating their own process and protecting the rule of law and the integrity of the jurisdiction from attack (Green, 2014, pp.19-20). Also, judges are required to adhere to a particular type of conduct that corresponds to the judicial office. In this regard, the Bangalore Principles on Judicial Conduct also provide guidance.

The Bangalore Principles identify six fundamental values that "afford the judiciary a framework for regulating judicial conduct" (Strengthening Judicial Integrity, 2002). These values are independence, impartiality, integrity, propriety, equality, competence, and diligence. The Principles are said to give expression to the highest traditions relating to the judicial function as visualized in all cultures and legal systems, and many states have modeled their principles of judicial conduct on them (Commentary on The Bangalore Principles of Judicial Conduct, 2007). Cowen has also highlighted that potential judges need to have forensic abilities, an appreciation of the practical workings of court procedure, a thorough knowledge of the law, an appreciation of ethical duties, and independent-mindedness (Cowen, 2013). The obligations described here, and the abilities and conduct expected of judges, as outlined by the Bangalore Principles and Cowen, are not only inherent in men. This has been proven over the decades, as the legal profession has gradually embraced women. Consequently, women have proven their capabilities and competence by ascending to the judiciary. 
Table 11.1 Gender breakdown of the courts as of $2018^{4}$

\begin{tabular}{llll}
\hline Court & Total \# of judges & $\begin{array}{l}\text { Female } \\
(\%)\end{array}$ & $\begin{array}{l}\text { Male } \\
(\%)\end{array}$ \\
\hline Constitutional Court & 7 & $4(57 \%)$ & $3(43 \%)$ \\
Supreme Court of Appeal & 13 & $4(31 \%)$ & $9(69 \%)$ \\
Court of Appeal & 12 & $7(58 \%)$ & $5(42 \%)$ \\
Specialized High Court Divisions & 40 & $23(57.5 \%)$ & $17(43.5 \%)$ \\
Overall Composition & 72 & $38(53 \%)$ & $34(47 \%)$ \\
\hline
\end{tabular}

Data obtained from the website of the Zambian Judiciary

Therefore, Zambia is to be commended in this regard, because it has achieved gender equity on the Superior Courts, as presented in Table 11.1.

Cook (1984) describes two primary patterns regarding the distributive representation of women in the judiciary, which are useful in assessing the figures presented earlier: namely, the pyramid pattern and the inverted bell pattern. In terms of the pyramid pattern, women have greater access to entering courts that are at the bottom of the pyramid (ordinary High Courts) than courts at the top (Appellate Courts). In terms of the inverted bell pattern, women have access as token representatives to the top and bottom court levels but not at significant trial court levels. Pointedly, the Zambian data outlined here follows neither of these patterns. In the Zambian scenario, women are represented well in the Constitutional Court and Court of Appeal in addition to the High Courts. This was not the case in 2011, when Ndulo (2011) lamented the scarcity of women in the apex courts in Zambia. To assist with the paucity of women in the judiciary at the time, he suggested a fast-tracking of women candidates, whereby preference would be given to a woman candidate if she was meritorious. Seven years later, the composition is admirable without the creation of a fast-tracking program, but this does not mean that societal discrimination is absent.

\section{Women's experience in the judicial and legal realm}

\section{When women are outsiders on the bench}

Traditionally, women have been characterized as agents of reproduction, which has resulted in women's confinement to the private sphere of home and family. In contrast, the public sphere of politics and work has been considered as the male sphere of endeavor (Thornton, 1985). Despite the image of Lady Justice, the judge is invariably masculinized. Women, people of color, and those who do not fit the dominant male narrative are marked as "other," which taints the adjudicative role and renders the delivery of justice problematic (Thornton, 2007). As Malleson argues, "almost without exception, official expressions of support for proactive measures to encourage diversity have been qualified by a statement of commitment to a strict application of the merit principle" (2006, p.131). Mcloughlin points out that "when eminent men are appointed judges, 
little is said on the matter as it is taken for granted that they are appointed on the basis of merit, and yet merit is determined in the context of power" (McLoughlin 2015, p.168.). Inevitably, those who are outside the dominant group culturally and economically (or who have not managed the skill to mimic the attributes and attitudes of the culturally and economically dominant group) are often dismissed as not possessing the requisite "merit" to be appointed to higher positions (de Vos, 2013).

Those who are considered meritorious are men who have been in dominant positions of power for so long that they are the standard for who is worthy of being a judge. Even when women have proved themselves as fit to be appointed, they still face challenges on the bench. According to Rackley (2007), a growing collection of tales show women as "remote beacons in hostile environments, whose presence deviates from the judicial norm and disrupts homogeneity on the bench" (p.76). This reveals the unavoidable, yet mostly unacknowledged, gender dimensions to traditional understandings of adjudication (Rackley, 2007). In other instances, "women have to work harder and extra just to be acknowledged," because appointment to the bench does not mean that their capabilities will stop being undermined and questioned (Mocumie, 2017, p.7). In Brazil, empirical research on the Supreme Court revealed that justices on the court are more likely to dissent when the leading judgment was written by a woman, and women judgment writers attracted more dissenting opinions than male justices (Carvalho, 2018). The researchers attribute this to the view that male justices are more likely to view their women counterparts as less competent, knowledgeable, or reliable, and they are less likely to be worried about a strain on the collegiality between colleagues.

World-renowned jurist Justice Florence Mumba was the first woman judge appointed to the Zambian High Court in 1980, four decades ago. She wrote about what she refers to as her "first test of the prejudice" when she initially started presiding in trials at the International Criminal Tribunal for the former Yugoslavia (Mumba, 2018). Some interpreters at the tribunal refused to commence trial at the mandated time of 8:30 am. Upon making enquiries, she learned that the interpreters started trial at 8:30 am for her male colleagues, and she realized that they had refused to do so for her because she was a woman. She decided that she had to assert her authority as a judge like everybody else, which meant "no soft robes." This meant that she had to put her foot down and demand the same respect afforded to male judges. Thus, even when women are finally appointed to the bench, they still face a hostile environment.

\section{Women as illegitimate holders of power}

Andre Vial et al. (2016) use a model centered on legitimacy to explain the persistence of the gender gap in leadership positions. They describe legitimacy as the sense of obligation or duty to comply freely with the decisions and directions of authorities (Vial, Napier, \& Brescoll, 2016). They posit that the difficulties that female leaders face often stem from low legitimacy perceptions. That is, powerful 


\section{Tabeth Masengu}

women (those with the means to make a societal impact), relative to powerful men, are less likely to be perceived as legitimate authorities. Other theories account for the difficulties that women face by positing women as norm violators.

In contrast, Vial et al. examine the questions that emerge when bias against female leaders is thought of as a particular case of bias against an illegitimate leader (Vial et al. 2016, p.401). In essence, the focus is not on the women as "disruptors" and unusual power holders, which results in bias, but rather, on the perspective that the women are undeserving of the authority that they wield. Within this, power, status, and legitimacy are distinct but intimately related constructs. Power comes attached to the leadership role, but legitimacy is a state in which a leader's power over others is seen as deserved and justified (Vial et al., 2016). People who occupy a low-level status are more likely to face negative presumptions about their competence and trustworthiness. Hence, when they assume leadership positions, they are viewed as illegitimate power holders.

\section{The experience of women in positions of power in Zambia}

Historically, women in Zambia have mainly been stereotyped as housewives, while men tended to present themselves as masters of their households. Public leadership has also been male-dominated: women's prescribed role has been to support men's endeavors (Evans, 2014). According to Evans (2014), the few women elected to public office endured tremendous scrutiny regarding their sexuality and morality; they were mocked if too timid, chastised if overly aggressive, and generally denied respect. Widely perceived as deviating from prescriptive gender stereotypes, female leaders might at best be accepted as "honorary men" (Evans, 2014, pp.981-982). Evans has theorized that in the Zambian political arena, "the limited supply of women candidates for public office may not be due to their gendered self-perceptions or internalized stereotypes." Instead, it is because of the anticipated penalties incurred by transgressing (or even openly questioning) cultural expectations (Evans, 2016, p.392). Even in a constitutional process that has long been an Achilles heel in Zambian history, women were repeatedly under-represented in constitutional reform bodies and the National Constitutional Conference in 2017 (Masengu, 2015). The research on the constitutional process found that the poor representation of women was not as a result of any passivity on the part of the women. Instead, it was an expression of the patriarchal nature of Zambian society, which affects all spheres, including law (Masengu, 2015).

The conservative nature of Zambian society, which is deeply religious, further endorses gender status beliefs. These beliefs assume that men are more suited to and deserving of positions of influence and esteem in a broad range of social and economic domains (Evans, 2016). Nonetheless, Evans' studies on women in politics in the north of the country showed that incrementally, Zambian women are being recognized and supported as independent actors and increasingly stepping into historically male-dominated and socially valued domains (Evans, 2016). Since the Patriotic Front (PF) came into government in 2011, there has been a 
concerted political will to include more women in top decision-making positions. There is limited data available to explain what prompted this decision, and there is insufficient data available to suggest that it could be because more women were qualifying with the requisite experience. An interview participant alluded to the SADC gender quotas or possibly the need to gratify donors as the reason why the PF sought to promote women, but this was unsubstantiated information. What is known is that former President Michael Sata appointed several women into various decision-making positions in all sectors. This included the appointment of the first ever woman Inspector General of Police, an acting woman Chief Justice, and a woman Deputy Chief Justice at the same time. ${ }^{5}$ His successor Edgar Lungu continued this commitment by selecting a woman Vice President, appointing the first ever permanent Chief Justice, Irene Mambilima, and the first woman Director of Public Prosecution (DPP). ${ }^{6}$ Despite these appointments, women still face an extra layer of judgment, which would not apply to men.

In an article about how Zambian women have "failed" the country, Richard W epitomizes the nature of the sexist judgment that women have often had to face (W, 2018). He accuses particular Zambian women, including former Chief Justice Irene Mambilima, Vice President, and DPP, of not being vigilant enough. He argues that they have "sunk into the political sofas, sipping coffee, and chatting about which part of Dubai they can find nice heels and wigs" (W, 2018). He urges women to qualify and earn their positions through competence and not motherliness and to avoid falling into the male trap of normalizing corruption and political manipulation. Ironically, he encourages women to fight sexism. Yet in the same breath, he admits in passing that his article does not seek to overlook the many contributions the said women have made (W, 2018). The writer expresses disappointment in "these" women while accepting the frailties of the male species. He expects these women to be without blame, thereby demonstrating the skewed framework facing women in influential positions. This asymmetric framework is exemplified further in a discussion later, focusing on appointments to the Constitutional Court.

Due to the scarcity of literature on gender and judging in Zambia, I cannot draw on previous studies in the judiciary attesting to the odd situation that women face. Therefore, reliance is placed on my interview data as a source of Zambian women's experience on the bench. However, the inaugural woman president of the Zambian Law Association (LAZ), Linda Kasonde, has spoken openly about the challenges she faced as a leader in the profession. In her article calling for more women in leadership, she states:

I cannot do that without talking about how insidious unconscious bias is. As a female leader in the public eye, you must be prepared for a lot of criticism, sexual objectification, and even threats to your personal safety. Women leaders also experience very personal attacks on social media. That is why we need to build a critical mass of women in leadership. Not only will it allow men and women to see women in leadership as a normal thing, but it will also create a bigger support network for women in leadership.

(Kasonde, 2018) 


\section{Tabeth Masengu}

Ms. Mbikusita-Lewanika, a seasoned politician and the first woman to ever run for the Zambian presidency in 2001, has also highlighted the difficulty of women in leadership. In her comments, she said, "when you have young children, you have to rush home while your male counterparts carry on with discussions in the bars or the chambers of parliament" (Mutame, 2012). Consequently, she opined that if a woman wanted to pursue politics in addition to being a wife and a mother, it would be necessary to have support from her husband. This example highlights both the role of primary caregiver that men do not often have and the tension between the private and the public sphere.

\section{Backing the wrong horse? Do women meet the requirements for judicial office?}

\section{The appointment process and criteria to be a judge}

The Judicial Service Commission (JSC) is responsible for appointing judges in Zambia. The JSC has proved to be an ally for women, as it has actively engaged in the promotion of women to the bench in Zambia, unlike in some other countries, where JSCs are stumbling blocks to women's appointment to the bench (Dawuni \& Masengu, 2019). The JSC sends out communications about vacancies to the LAZ, the internal judiciary mailing system, and government and parastatal companies (Masengu, 2017a). Candidates apply, and the JSC interviews the shortlisted ones. Names of selected candidates are sent to the President for appointment, subject to ratification by the National Assembly as per section 140 of the Constitution of Zambia Amendment Act 2016 (hereafter the constitution). A parliamentary select committee further interviews the candidates before the names are sent to the main house in the National Assembly for a vote.

I asked the interview participants to comment on the criteria to be a good judge. All the participants referred to the constitutional criteria as the starting point for judicial office. These criteria are what I refer to as constitutional requirements for judicial office, which are found in section 141 of the constitution. It states that:

(1) A person qualifies for appointment as a judge if that person is of proven integrity and has been a legal practitioner, in the case of the-

(a) Supreme Court, for at least fifteen years;

(b) Constitutional Court, for at least fifteen years and has specialized training or experience in human rights or constitutional law;

(c) Court of Appeal, for at least twelve years; or

(d) High Court, for at least ten years.

(2) A person appointed as judge to a specialized court shall have the relevant expertise, as prescribed.

In addition to the constitutional requirements, when the JSC is assessing a candidate in privately conducted interviews, it refers to additional criteria. Here, 
the focus is on professional qualifications and character traits. The guiding philosophy of the JSC is that candidates should have extensive experience in legal work acquired either from private practice, from the bench, or from public service (Zambian Judicial Service Commission, 1993). The criteria also state that a record of competence must be established through recommendations or references, and they must have a lengthy post-call period of legal experience before an appointment. ${ }^{7}$ Unquestionable integrity, suitable temperament, patience, and impartial disposition, objectivity, and courage are also essential. The criteria particularly mention the desire for candidates without strong business interests, since strong business interests are considered as a potential area where conflict could arise if one is on the bench. ${ }^{8}$

There were varying views from interview participants concerning what is required from candidates aspiring for judicial office. The top three identified character criteria for good judges were integrity, competence, and experience. Regarding integrity, former JSC Commissioner Mr. Fraser Chishimba submitted that integrity is not a moral question but instead, it is about professional reputation. ${ }^{9}$ This was disputed by the current Chair of the JSC, former Chief Justice Mathew Ngulube, who averred that despite how brilliant they may be, a person with integrity could not be "morally bankrupt." Another former commissioner emphasized the need for candidates to be of sound character and have no "skeletons" in their closet. ${ }^{10}$ When describing competence, participants emphasized the importance of an ability to write clear and precise judgments, prepare for trials, and have an understanding of the judicial role. The relevant experience was highlighted as a mandatory requirement, because previously, people were appointed when they had not been in roles that actively engaged with the law. ${ }^{11}$ Thus, experience as a legal practitioner with related responsibilities over the years was discussed as the best way to gauge knowledge. ${ }^{12}$

Other additional requirements included honesty, efficiency, expertise, intellectual capacity, ability to be non-partisan, and commitment to the judicial role. There was a unanimous view that this criterion was not exclusive to men and that women could and did possess these qualities. Thus, how meritorious a candidate is, is independent of their gender. We are made to believe that the definition of merit is neutral because merit is the quality of excellence and great worth (Davis $\&$ Williams, 2003). Yet, "the best person to occupy a position of authority has tended to be unproblematically defined in masculinist terms that reflect the values of the public sphere" (Davis \& Williams, 2003, 831; Olivier, 2013; Malleson, 2006). The values of the public sphere and the perceptions of who is deserving of influential roles are evident in the skepticism toward women judges in Zambia.

\section{Skepticism about the appointment of women judges}

None of the JSC members I interviewed expressed any concern about the performance or capabilities of women judges. There were, however, four views from the legal professionals and Non-Governmental Organization (NGO) members that relayed skepticism about the competence and capability of women judges. 


\section{Tabeth Masengu}

The first view was that there were better-qualified men who should have been appointed in the same period..$^{13}$ This view was expressed by two men. One is a registrar, who is possibly in the pipeline for future judgeship himself and the other a resident magistrate. A second view was submitted by Advocate Sangwa $\mathrm{SC}$, a well-known and highly respected senior advocate. His view was that there were more women on the bench because they had failed to succeed in private practice ${ }^{14} \mathrm{He}$ posited that in his many years of legal practice, he had witnessed a fall in jurisprudential standards and an increase in delayed judgments. Thirdly, it was argued that there was a certain threshold one could reach in public service. This was opined by a qualified advocate currently in a position of responsibility in academia. She pointed out that since there were more women in public service, judicial appointments were a tool to "move officers around and to get desired political appointees in specific public offices." ${ }^{15} \mathrm{Mr}$. Mweenge, a senior member of the local branch of an international NGO, however, offered a different and final assertion relating to women judges. He argued that while women were being appointed to high positions, they did not have the autonomy to work independently. "An invisible hand" that made them more likely to "play out some favors" impeded their independence. ${ }^{16}$ Effectively, the judges would not be individually independent, because they would owe allegiance to others.

\section{Establishing the validity of the skepticism regarding women judges}

In respect of the first claim, there is no indication that the "better-qualified" men referred to by the Registrar and Magistrate did apply for and were rejected for judicial positions. Nevertheless, a few participants used the Constitutional Court judgment in Hakainde Hichilema $\mathcal{E}$ Others v Edgar Lungu $\mathcal{E}$ Others as evidence that women lack the required competencies. ${ }^{17}$ In this matter, the newly established Constitutional Court had refused to hear a much-anticipated election petition that challenged the re-election of Edgar Lungu and Inonge Wina as President and Vice President of the Republic of Zambia, respectively, due to fraud. ${ }^{18}$ The court found that the petition failed on a technicality and not because there was no substantive case to be heard. This decision was made despite an earlier assurance that the court would listen to substantive arguments. ${ }^{19}$ At the time, the court was comprised of two men and four women, although only five members heard the election petition case (three of them were women). Further, two participants also referred to a public memorandum written by Advocate John Sangwa SC, mentioned earlier. Advocate Sangwa had expressed dissatisfaction with the initial selection of the Constitutional Court judges, and decision in this Constitutional Court case was advanced as proof of Advocate Sangwa's warning.

The warning was in the form of a lengthy and scathing document. The document commenced with a historical overview of why the Constitutional Court was established. It was then submitted that all six candidates did not have the requisite number of years of actively practicing law and were all unqualified for the position. Sangwa alleged that the selected judges lacked working experience in prosecuting constitutional or human rights-related cases (Sangwa, 2016). Notwithstanding 
this, it is suggested that using the Constitutional Court judgments as a means of appraising women's competency and capabilities is flawed for the following reasons. One woman justice and two male justices wrote the majority judgment, which was roundly criticized. Women wrote both dissenting opinions, which held that the petition should have been heard. Therefore, by apportioning blame to the women justices, these critics absolved the men who co-wrote that majority judgment of any responsibility. Secondly, the assessment by Advocate Sangwa that the Constitutional Court judges were unqualified applied to all the judges, not just the women. Therefore, using the said assessment as evidence of women's failings is discriminatory, because it is being applied to women and not to men. This discrepancy in treatment led an interview participant to opine that the Constitutional Court is not respected simply because the majority of its justices are women. ${ }^{20}$

Further, it is essential to consider the role that informal political networks play in supporting women leaders and the effect of an absence of such political networks. Research has shown that the formation of a successful unified women's movement was pivotal in supporting the rise of women legislators in Rwanda, South Africa, and Uganda (Conner, 2008). A vibrant and strong legacy of civil society movements and strong international women's rights networks helped women navigate spheres of legislative power previously dominated by men (Bauer \& Burnet, 2013). These social movements have the possibility of supporting and defending women when citizens wrongly criticize them. However, Zambian women judges are not privy to networks that can defend against false allegations of incompetence. Unlike legislators, judges have to maintain a certain distance from the public to avoid impropriety and to prevent claims of bias if any supporting movement comes to court. Women judges are natural targets because they lack women's support systems and the long-established support structures formed by the "old boys club" of lawyers and judges.

The second claim for the skepticism centered on a high attrition of women from private practice to the bench. Yet, there was no specific evidence of more women having left private practice to join the bench, and Advocate Sangwa did concede that the problem could apply to both men and women. Further on in my research, I also discovered that a fair number of judges had come from the public service and the judiciary itself and not private practice. The women concerned deliberately chose to pursue their legal careers outside public practice. There is insufficient data available to tabulate the exact numbers of women versus men who have come from private practice service in a particular period (in comparison to men). However, a perusal of the biographies of the justices of the Supreme Court showed that both men and women justices worked in public service before appointment to the bench. ${ }^{21}$ This refutes the argument that the women who came to the bench were "failures" in private practice. Also, the view that women may have failed in private practice is indicative of the archaic notion that the best judges must be litigators. There is no evidence to show that this is the case. If one considers the issue of delayed judgments, in the period 2013-2017, there was only one reported investigation probing judicial misconduct arising from delayed judgments. 
In September 2013, then President Michael Sata suspended High Court judges Emelia Sunkutu and Timothy Katanekwa and instituted a tribunal to probe them for professional misconduct. ${ }^{22}$ One judge was a woman, and one was a man. They were eventually cleared of the charges, and their suspension was lifted. The tribunal held that they were not at fault, as the delays in judgments were occasioned by the fact that they were transferred continuously from one town to another.

I was unable to collect sufficient data to test the third claim, that women were moved around in public service. This theory could be confirmed or disproved by examining the number of women judges who have come from the public service in a particular period (in comparison to men). A perusal of the biographies of the justices of the Supreme Court, however, showed that there were a number of both men and women justices who worked in public service before appointment to the bench. ${ }^{23}$ This is not uncommon. The Chairperson of the JSC informed me that historically, judges were chosen from within the judiciary-from registrars and magistrates. ${ }^{24}$ It is only in the last two decades that candidates from private practice have been considered. What is ironic is that this move to include a previously neglected pool of candidates has resulted in the belief that that pool has a monopoly on the requisite judicial criteria.

I submit that the final claim expressed by Mr. Mweenge regarding the lack of independence among women judges is informed by one instance-the tenure of one particular woman justice. It is therefore necessary to explore this circumstance in more detail.

\section{Justice Lombe Chibesakunda's tenure as Acting Chief Justice}

Justice Lombe Chibesakunda was the first woman lawyer admitted to the Bar in Zambia in 1969 (Mumba, 2018). She served as a justice of the Supreme Court of Zambia until June 2012, when she was appointed as Acting Chief Justice by then President Michael Sata. At the time of her appointment, Chibesakunda had already reached the stipulated retirement age of 65. Still, the President relied on Article 93 (6) of the 1996 constitution, which stated that "a person may act as the Chief Justice, Deputy Chief Justice or a Supreme Court judge notwithstanding that they had attained the age prescribed by article 98" (The Government of Zambia, 1996). There were allegations that Sata appointed her because she was his cousin, (Munshya, 2013). The proposal to ratify did not proceed to the main parliamentary house after it failed before the Select Committee and it was eventually withdrawn. However, President Sata ignored the non-ratification and other legal challenges, and Chibesakunda's term only came to an end in 2015 when a new President was elected. ${ }^{25}$ What is considered more alarming to critics was the politicization of the judiciary during Chibesakunda's reign as Acting Chief Justice.

In the controversial case of Mutuna 83 Others v. Attorney Generall ${ }^{26}$ on May 12, 2012, the President unilaterally suspended three judges without following due process as prescribed under the Judicial Code of Conduct Act No. 13 of 1999. The three judges were granted an exparte order for leave to apply for judicial review and a stay of 
the President's decision on May 14. The Attorney General appealed to the Supreme Court after a bid to discharge the leave failed; the Supreme Court of Appeal by a majority of 4 to 3, with Chibesakunda delivering the majority judgment, found that there was no condition precedent to the President's exercising the powers vested in him under Articles 98(2), (3), and (5). ${ }^{27}$ This decision was widely criticized, ${ }^{28}$ with renowned academic Muna Ndulo stating that Article 98 had not been drafted to become the conduit of executive influence over the judiciary. He went on to state that removing judges from the bench on spurious grounds was the greatest threat to judicial independence (Ndulo, 2016). Some considered Chibesakunda's decision in this case as a move to curry favor with Sata and ensure that she would be permanently appointed as Chief Justice (Munshya 2013). This is despite the fact that it was a unanimous court decision and other justices could have dissented if they thought the main judgment was incorrect.

In addition, during her tenure, the Supreme Court nullified several parliamentary seats that were the subject of a petition by the ruling party. Some election petitions were alleged to have been decided in favor of the ruling PF, as most of the subsequent by-elections resulted in the vacant seat falling to the ruling party (Freedom House, 2014). However, once again, it is difficult to prove any undue influence exerted by the former Chief Justice. All the discussions of the justices of the Supreme Court were in camera, and the decisions were passed by a majority bench. Thus, it was arguable whether Justice Chibesakunda's period as Acting Chief Justice was tainted because of alleged judgments in favor of the ruling party. Her refusal to step down even when the National Assembly refused to ratify her, however, indicates bad judgment on her part. Nonetheless, it would be unfair to judge women based on Chibesakunda's acting tenure, because succeeding male leaders have not been judged based on their predecessors' actions. Before her extended tenure as Acting Chief Justice, Chibesakunda had distinguished herself well on the Supreme Court.

Secondly, in 2002, a male Chief Justice, Mathew Ngulube, stepped down after allegations of corruption after he was alleged to have received large amounts of money from previous President Frederick Chiluba (Daily Nation, 2015). Justice Ngulube was eventually cleared because he did not know that the source of the gift was government funds, and he paid back the money to the government. However, a critic could argue that the fact that he accepted a monetary gift from the then sitting President was also an instance of bad judgment. No reference was made to this and other indiscretions of male judges, which begs the question: "Why is the lack of judicial independence a reason for skepticism concerning women and not men?" I submit that this is because of the differentiation made between male judges and women judges; more precisely, the view that women judges are considered as illegitimate holders of power.

Hence, we see that historical perceptions of women have not disappeared as women have entered politics, governance, and other professions. Instead, they have morphed into prejudice and illegitimacy perceptions of women in respect of women leaders. Studies suggest that traditional sex-role stereotypes are imperative for understanding the dynamics and expectations for women and men in leadership (Adebayo $\&$ Udegbe, 2004). In the Zambian scenario, the majority of interview participants 


\section{Tabeth Masengu}

perceive women judges as illegitimate holders of power because they assume that these women lack the required competencies and capabilities. The low legitimacy perceptions of women mean that even though they have the authority to preside, opinions are that their power is unjustified and undeserved.

\section{The effects of perceptions of illegitimacy}

\section{Prejudice toward women judges}

The perceived mismatch or lack of fit between the traits seen as typical behaviors of leaders and those considered to be characteristic of women drives expectations that women will be less competent than men with identical credentials (Vial et al., 2016, p.403). This mismatch between the behavior of "typical" leaders and women results in prejudice. This is known as the role congruity theory. Eagly and Karau suggest that in general, prejudice toward female leaders follows from the incongruity that many people perceive between the characteristics of women and the requirements of leadership roles (Eagly \& Karau, 2002). The potential for prejudice against women leaders that is inherent in the female gender role follows from its dissimilarity to the expectations that people typically have about leaders. Prejudice can arise when perceivers judge women as actual or potential occupants of leadership roles. The judgment stems from the inconsistency between the predominantly communal qualities that perceivers associate with women and the predominantly agentic attributes they believe are required to succeed as a leader (Eagly \& Karau, 2002, p.575). In short, because women are not ordinarily considered as convincing, authoritative, independent, and assertive actors, any role that affirms these qualities activates prejudice.

As mentioned earlier, women in Zambia have previously played a supporting role and are latecomers to governance and politics. This subordinate role is contrary to positions of authority such as judging, and an interview participant, $\mathrm{Mr}$. Habasonda, aptly explains this:

The women participating on the bench are also informed in the traditional lenses that we find in the society that we are anchored in. The fact that those women are not necessarily able to resolve conflict within society. I think that our chiefdoms are in such a way that men take the lead, even in situations where the woman is the chief; it is the men surrounding her that make the decision. ${ }^{29}$

Thus, the idea of a woman taking the lead is historically incongruent with what is expected of her; worse yet for the role of a judge, which requires a woman to take charge of a courtroom and decide matters, sometimes matters of life and death, and to admonish lawyers when necessary. The reference to the Constitutional Court decision as proof of women's failures is a fitting example. The male justices who signed on to the majority judgment were not criticized, nor were their actions considered as proof of their incapabilities. The role of men as justices is 
uncontested, or rather, it does not violate any expectations, because they are expected to be holders of this power. The women, on the other hand, are singled out as proof that women are not up to the task, even though there is no empirical evidence to support this argument. Three legal professionals suggested that though there has been a drop in standards regarding quality of judgments, this was across the board. One legal professional expressed concern about placing the blame for "falling" standards on women, and she wondered whether the judgments were better than they currently are when the bench was male-dominated. ${ }^{30}$ When asked why there was a perception that women were to blame for the challenges of the judiciary, some participants alluded to societal attitudes of women and general sexism as reasons why women continued to be judged unkindly.

One legal professional mentioned that men are more prominent or reported more in the media than women lawyers. ${ }^{31}$ Thus, because women were less prominent lawyers, they were less likely to be perceived as the ideal judge in comparison to men. Invariably, this means that they are less likely to be perceived as deserving of the judicial power that is accorded to judges, thereby invoking perceptions of illegitimacy. These societal perceptions of women are a result of the incongruence of the role of the judge and women's role in society. It is suggested that they also result from a belief that there has been a violation of the standard mode of operation, where men are expected to dominate every sphere of society-including the judiciary. The statistics in the judiciary point to how this belief has been disrupted, but they also fuel the need to explain why the feminization of the judiciary is not justified. These explanations come in the form of suggestions that jurisprudential standards are falling, that women judges lack autonomy, or even that women perceive the bench as a more relaxed environment than private practice. Irrespective of which argument is tendered, it originates from the same source-low perceptions of women's legitimacy.

\section{The effect of these perceptions on women and judicial governance}

Legitimacy occurs when the power of those who have it is seen as deserved and justified. The perceptions of legitimacy concerning judges affect the overall legitimacy of the courts. In the introduction, I listed three reasons for how the overall legitimacy of the courts is affected. However, there are also consequences for the individual women judges, because women judges have the power to adjudicate. The perceptions that this power is not justified can affect their work. Through my interviews with the women judges and women legal professionals, I found empirical evidence that the occupation of a high-rank position by a person belonging to a group that occupies a subordinate role in society did lead to negative reception. The consequence of this amongst the judges I interviewed was that they felt that they had to prove themselves and to justify their positions. For example, one justice mentioned that there are higher expectations of women judges in comparison to men. She said:

[t]hey said at the workshop that the women judges were not performing as expected. And yet there had been men for many years who were 


\section{Tabeth Masengu}

underperforming, and they had made many mistakes, and now it was interesting that because it was women judges, suddenly there was a problem. ${ }^{32}$

She noted that women are often placed under a microscope. The focus on women judges at the workshop in question was also without merit, as no factual evidence led to showing that women were not performing as expected. It was a general statement that cast aspersions on all women judges, which, another judge submitted, are because of cultural constructs. She posited that "if a woman fails to perform, they will attack her more" than they would a man. ${ }^{33}$ Thus, in addition to working hard, being diligent and consistent were perceived as the only other ways to mitigate the effect of these negative perceptions.

This is not unusual. Studies have shown that women are evaluated less favorably, even when performing precisely the same leadership roles as men (Ryan et al., 2016). Further, women candidates for high positions are more likely to receive more negative media coverage (Brenner \& Knake, 2012). They are more likely to be judged on dressing, their gender is more likely to be mentioned, and their family life is mentioned more frequently than men's (Brenner \& Knake, 2012). Societal perceptions of gender roles are also present in interviews for the selection of judges, and I obtained empirical data supporting this. One former JSC commissioner spoke of her surprise at how candidates were treated differently in interviews. She noticed that only women were asked questions about what would happen if their husband was transferred to another town or if they had to be moved. ${ }^{34}$ She stated that she found these questions problematic because they were not asked of male candidates. These questions placed the women in the traditional and private sphere of wife and homemaker. The implication here was that their desire to be in positions of power is incompatible with their expected gender role, while for men, this disjuncture is absent; hence the ease with which they are considered legitimate power holders.

The women judges I interviewed in Zambia did acknowledge the challenges of having to balance their family roles and their work. They concluded that the capabilities and competencies required to be a judge or the qualities of a good judge were not the stumbling blocks in their career. Rather, it was the strain of balancing family responsibilities and burdens (which are expected of women in Zambia) that sometimes put them at a disadvantage in relation to their male colleagues.

Illegitimacy perceptions that result in women having to prove themselves can also have a detrimental effect on the women judges themselves. I submit that in trying to prove themselves, they may take on more cases than they should, leaving them exhausted from carrying a heavier workload. There is another possible effect of illegitimacy perceptions evidenced in other studies. When women prove that they are as competent as their male colleagues, either by having a firm hand in court proceedings or by being assertive with lawyers, they will face backlash for "acting like men." Godsil et al. (2016) refer to this as penalizing women for not meeting gendered expectations of female friendliness and gentleness. It is important to remember that attaining the role of a judicial officer is not a menial exercise. Unlike the legislature or executive, where members do not necessarily have to hold professional qualifications to attain positions, the judiciary is a different arena. 
While character traits such as honesty, integrity, equality, and propriety can be found in a large number of people, competence in legal matters, university qualifications, and subsequent further legal training cannot. One has to have reached a certain professional level to meet the constitutional requirements mentioned in the first part of this chapter and the additional criteria required by the JSC. Current and former commissioners interviewed stated that women are more likely to have higher postgraduate qualifications than men. In the last two years, they have performed better in JSC interviews than men have. If women have more impressive qualifications and interviews at the JSC than men, and they pass scrutiny at the National Assembly, is it fair that they are perceived as illegitimate merely because they are perceived as the "second" sex?

\section{Conclusion}

In this chapter, I have argued that despite the commendable equitable representation of women in the Zambian judiciary, women still face skepticism primarily based on perceptions of illegitimacy. I have located these perceptions within the perceived incongruence between women's characteristics or traditional roles in society and a leader's qualities. I use the argument that women are perceived as unjustified power holders, as opposed to norm violators, because of data I gathered during my interviews, which are corroborated by existing research. Increasingly, the majority of law school students and graduates are women, so it is not a field with a lack of women. It is the role of the judge, with power, privilege, and responsibilities, that is considered by some as "too much" for many women to have. I acknowledge that the judiciary in Zambia is unique in that women occupy high positions, which is both unusual and different, especially compared with other branches of government. However, this particular situation does not merit the view that women are undeserving of being the majority and serving as leaders in the judiciary. It is undeniable that the illegitimacy perceptions discussed in this essay are buttressed by cultural and social constructs of womanhood in Zambia. There is no evidence to suggest that women judges are performing worse than men are or are bringing the judiciary into disrepute. A research project on court efficiency and justice is currently underway by a reputable research institution, which seeks to provide policymaking, research capacity, and governance. ${ }^{35}$ While preliminary results indicate that there are some issues with performance and case mismanagement, there is no evidence as yet that this is attributable to the feminization of the judiciary. ${ }^{36}$

\section{Notes}

1 Norway, Sweden, and Finland have long been lauded for their gender-equitable parliaments.

2 Statistics obtained from http://www.parliament.gov.zm/members/gender and http:// www.parliament.gov.zm/ministers/cabinet.

3 Most of these interviews were conducted in the capital city Lusaka, with a few from Kitwe, the second largest city in the country. 


\section{Tabeth Masengu}

4 The statistics were obtained from the website of the Judiciary of Zambia in April, 2018. See http://www.judiciaryzambia.com.

5 Justices Lombe Chibesa-Kunda and Florence Mumba, respectively.

6 Vice President Inonge Wina is serving her second term in office, while DPP Lillian Fulata Shawa-Siyuni was appointed in 2016.

7 The call period is the training at the Zambian Institute of Advanced Legal Studies and admission as an Advocate.

8 Interview with Deputy Chief Justice (DCJ) Marvin Mwanamwambwa on December 1, 2016 in Lusaka, Zambia.

9 Interview on April 12, 2017 in Lusaka, Zambia.

10 Interview with Commissioner 1, April 21, 2017, Lusaka, Zambia.

11 An example of the appointment of a previous Registrar of Companies was cited here.

12 Interview with Judge 4, April 18, 2017, Lusaka, Zambia.

13 Interview with Legal Professional 1, August 15, 2017, Kitwe, Zambia.

14 Interview with Legal Professional 3, August 14, 2017.

15 Interview with Legal Professional 2, April 19, 2017, Lusaka, Zambia.

16 Interview with Mr. Mweenge, April 18, 2017, Lusaka, Zambia.

17 (Hakainde Hichilema $\mathcal{E}$ Others $v$ Edgar Lungu $\mathcal{E}$ Others, 2016.)

18 President Edgar Lungu garnered 1,860,877 votes against the opposition United Party for National Development (UPND) Hakainde Hichilema's 1,760,347 votes.

19 For a detailed explanation, see Owiso, R. Zambia: The 2016 Zambia Presidential election petition: How not to handle election petitions. Retrieved from https://www.lusakatimes.com /2016/09/20/2016-zambia-presidential-election-petition-not-handle-election-petitions

20 Interview with Commissioner 1.

21 The website for the Zambian judiciary only contains short biographies of the judges of the Supreme Court.

22 Interview with Mr. Frederick Mudenda.

23 The website for the Zambian judiciary only contains short biographies of the judges of the Supreme Court.

24 Interview with former Chief Justice Mathew Ngulube.

25 The Law Association of Zambia mounted an unsuccessful legal challenge against Justice Chibesakunda's continued stay in office.

26 Appeal No. 088/2012 [2013] ZMSC 38 (9 May 2013); SCZ/8/185/2012.

27 Appeal No. 088/2012 [2013] ZMSC 38 (9 May 2013); SCZ/8/185/2012.

28 See Elias Munshya wa Munshya. With forked tongues: Why Chibesakunda's majority ruling in Attorney-General v. Mutuna \& Others is flawed. Retrieved from https ://eliasmunshya.org/2013/07/01/with-forked-tongues-why-chibesakundas-majority-ru ling-in-attorney-general-v-mutuna-others-is-flawed

29 Interview with Mr. Habasonda, April 19, 2017, Lusaka, Zambia.

30 Interview with Legal Professional 2, April 19, 2017.

31 Interview with Legal Professional 5, April 20, 2017.

32 Interview with Justice 2, April 18, 2017.

33 Interview with Judge 3, November 26, 2016.

34 At note 9 .

35 I am unable to identify the organization, as it would compromise the anonymity of the interview participant working on this project.

36 Interview with Legal Professional 6.

\section{References}

Adebayo, D.O., \& Udegbe, I.B. (2004). Gender in the Boss-Subordinate Relationship: A Nigerian Study. Journal of Organizational Behavior, 25(4), 515-525. https://doi.org/10 $.1002 /$ job. 255 
Albertyn, C. (2014). Judicial Diversity. In Cora Hoexter \& Morné Olivier (Eds.), The Judiciary in South Africa (pp. 245-287). Cape Town: JUTA.

Arrington, N., Bass, L., Glynn, A., Staton, J.K., Delgado, B., \& Lindberg, S.I. (2017). Gender Diversity on High Courts. Working Paper Series, 54. https:/www.researchgate. net/publication/320657176_Gender_Diversity_on_High_Courts

Bauer, G., \& Burnet, J.E. (2013). Gender Quotas, Democracy, and 'Women's Representation in Africa: Some Insights from Democratic Botswana and Autocratic Rwanda. 'Women's Studies International Forum, 41, 103-112. https://doi.org/10.1016/j.wsif.2013.05.012

Brenner, H., \& Knake, R.N. (2012). Rethinking Gender Equality in the Legal 'Profession's Pipeline to Power: A Study on Media Coverage of Supreme Court Nominees. Temple Law Review, 84(2), 325-384. Retrieved from https://www.scopus.com/inward/record.uri?eid= 2-s2.0-84861493752\& partnerID=40\& md5=9915447401171ed106b9d2c0341165dd

Carvalho, R. (2018). "They 'don't let us speak”: Gender relations and judicial decisionmaking in the Brazilian Supreme Court. Women, Gender $\mathcal{E}$ the Law Ejournal, 14(10). Retrieved from https://papers.ssrn.com/sol3/papers.cfm?abstract_id=3116338

Commentary on the Bangalore Principles of Judicial Conduct (2007). Vienna. Retrieved from https:/www.icj.org/wp-content/uploads/2014/10/Commentary-bangalore-pr inciples.pdf

Commonwealth. (2003). Commonwealth (Latimer House) Principles on the Three Branches of Government. Retrieved from http://www.cmja.org/downloads/latimerhou se/commprinthreearms.pdf

Conner, B. (2008). You Made a Mistake-You Selected Women: The Implementation of Political Gender Quotas in Postconflict African Nations. Tulane Journal of International and Comparative Law, 17, 1-26. Retrieved from http://heinonlinebackup.com/hol-cgi -bin/get_pdf.cgi?handle=hein.journals/tulicl17\&section=11

Cook, B.B. (1984). Women Judges: A Preface to Their History. Golden Gate University Law Review, 14(3), 1-38.

Cowen, S. (2013). Judicial Selection in South Africa (First). Cape town: Democratic Governance and Rights Unit.

Daily Nation (2015). Justice Ngulube Cleared. Retrieved March 25, 2019, from https://ww w.zambiadailynation.com/2015/04/09/justice-ngulube-cleared/

Davis, R., \& Williams, G. (2003). A Century of Appointments but Only One Woman. Alternative Law Journal, 28(2), 54-58.

Dawuni, J.J., \& Masengu, T. (2019). Judicial Service Commissions and the Appointment of Women to High Courts in Nigeria and Zambia. In S. Sterett \& L.D. Walker (Eds.), Research Handbook on Law and Courts (pp. 213-230). Northampton: Edward Elgar Publishing.

Devlin, R., MacKay, A.W., \& Kim, N. (2000). Reducing the Democratic Deficit: Representation, Diversity and the Canadian Judiciary, or towards a Triple P Judiciary. Alberta Law Review, 38, 734-865. Retrieved from http://heinonline.org/HOL/Page ?handle=hein.journals/alblr38\&id=746\&div=34\& collection=journals

Eagly, A.H., \& Karau, S.J. (2002). Role Congruity Theory of Prejudice Toward Female Leaders. Psychological Review, 109(3), 573-598. https://doi.org/10.1037//0033-295X. 109.3.573

Evans, A. (2014). "Women Can Do What Men Can Do": The Causes and Consequences of Growing Flexibility in Gender Divisions of Labour in Kitwe. "Women Can Do What Men Can Do': The Causes and Consequences of Growing Flexibility in Gender Divisions of Labour in Kitwe, Zambia. Journal of Southern African Studies, 40(5), 981998. https://doi.org/10.1080/03057070.2014.946214 


\section{Tabeth Masengu}

Evans, A. (2016). “For the Elections. We Want Women'!”: Closing the Gender Gap in Zambian Politics. Development and Change, 47(2), 388-411. https://doi.org/10.1111/ dech.12224

Freedom House (2014). Zambia | Freedom House. Retrieved March 25, 2019, from https ://freedomhouse.org/report/freedom-world/2014/zambia

Godsil, R.D., Tropp, L.R., Atiba, G.P., Jay, J., Powell, J., \& MacFarlane, J. (2016). The Effects of Gender Roles, Implicit Bias, and Stereotype Threat on the Lives of Women and Girls. Science of Equality, 2, 1-88.

Green, L. (2014). Law and the Role of a Judge (Legal Research Paper Series No. 47). Oxford. Retrieved from https://papers.ssrn.com/sol3/papers.cfm?abstract_id=249 5953

Grossman, N. (2012). Sex on the Bench: Do Women Judges Matter to the Legitimacy of International Courts? Chicago Journal of International Law, 12, 647-682. https://doi.org $/ 10.2139 /$ ssrn. 1773015

Hakainde Hichilema \& Others v Lungu \& Others (2016). (2016/CC/0031) ZMCC 4 (5 September 2016). https://zambialii.org/node/12445

Hirschl, R. (2008). The Judicialization of Mega-Politics and the Rise of Political Courts. Annual Review of Political Science, 11(1), 93-118. https://doi.org/10.1093/oxfordhb/97 80199208425.003 .0008

Kasonde, L. (2018). Why We Need More Women in Leadership. Retrieved May 28, 2018, from https://diggers.news/guest-diggers/2018/03/07/why-we-need-more-women-in-lea dership/

Malleson, K. (2006). Rethinking the Merit Principle in Judicial Selection. Journal of Law and in Society, 33(1), 126-140. https://doi.org/10.1111/j.1467-6478.2006.00351.x

Masengu, T. (2015). Standing on the Sidelines Watching: Women and 'Zambia's Constitutional Processes. In Constitution Building in Africa (pp. 48-74). Baden-Baden: Nomos.

Masengu, T. (2017a). Research Report on the Zambian Judicial Appointment System. Cape Town: Democratic Governance and Rights Unit.

Masengu, T. (2017b). The Vulnerability of Judges in Contemporary Africa: Alarming Trends Author(S). Africa Today, 63(4), 3-19.

McLoughlin, K. (2015). The Politics of Gender Diversity on the High Court of Australia. Alternative Law Journal, 40(3), 166-170. Retrieved from http://heinonline.org/HOL/ Page?handle $=$ hein.journals/alterlj40\& $\mathrm{id}=170 \&$ div $=46 \&$ collection $=$ journals

Mocumie, C.B. (2020, Forthcoming). Gender Transformation of the Judiciary in South Africa through the Eyes of a Woman Judge. Lanham: Lexington Books.

Mokgoro, Y. (2010). Judicial Appointments. Advocate, 23(3), 43-48.

Mumba, F.N.M. (2018). The Quest for Equal Opportunities. In J. Dawuni \& A. Kuenheyia (Eds.), International Courts and the African Woman Judge: Unveiled Narratives (pp. 2735). New York: Routledge.

Munshya, E. (2013). Kuya Bebele: Why Lombe Chibesakunda Should Vacate the Office of Chief Justice | Elias Munshya, LL.M, MBA, M.DIV. Retrieved February 5, 2019, from https://eliasmunshya.org/2013/09/11/kuya-bebele-why-lombe-chibesakunda-should-va cate-the-office-of-chief-justice/

Mutame, G. (2012). African Women Are Ready to Lead. Retrieved May 28, 2018, from https://www.un.org/africarenewal/magazine/special-edition-women-2012/african-wom en-are-ready-lead 
Ndulo, M. (2011). Judicial Reform, Constitutionalism and the Rule of Law in Zambia: From a Justice System to a Just System. Zambia Social Science Journal, 2(1), 1-26. Retrieved from http://scholarship.law.cornell.edu/zssj

Ndulo, M. (2016). Professor Muna Ndulo on Judicial Independence and Supreme 'Court's Decision in Matter of Three Judge. Retrieved April 20, 2016, from http://www.zamb iawatchdog.com/professor-muna-ndulo-on-judicial-independence-and-supreme-co urts-decision-in-matter-of-three-judges/

O' Regan, K. (2012). A Pillar of Democracy: Reflections on the Role and Work of the Constitutional Court of South Africa. Fordham Law Review, 81, 1169-1186

Olivier, M. (2013). A Perspective on Gender Transformation in the South African Judiciary. South African Law Journal, 13(3), 449-464

Owiso, R. (2016). Zambia : The 2016 Zambia Presidential Election Petition: How Not to Handle Election Petitions. Retrieved March 12, 2018, from https://www.lusakatimes .com/2016/09/20/2016-zambia-presidential-election-petition-not-handle-election-pet itions/

Rackley, E. (2007). Judicial Diversity, the Woman Judge and Fairy Tale Endings. Legal Studies, 27(1), 74-94.

Ryan, M.K., Haslam, S.A., Morgenroth, T., Stoker, J., Peters, K., Heilman, M., Peters, K., \& Ryan, M.K. (2016). Getting on top of the Glass Cliff: Reviewing a Decade of Evidence, Explanations, and Impact. The Leadership Quarterly, 27(3), 446-455. https:/ /doi.org/10.1016/j.leaqua.2015.10.008

Sangwa, S.J. (2016). Brief to the President of the Republic of Zambia on the Constitutional Court Appointments. Lusaka: Advocate John Sangwa

Solanke, I. (2008). Diversity and Independence in the European Court of Justice. Columbia Journal of European Law, 15, 89-121. Retrieved from https://www.copyright.com/ccc/ basicSearch.do?

Southern African Chief 'Justices' Forum (2018). Lilongwe Principles and Guidelines on the Selection and Appointment of Judicial Officers. Lilongwe. Retrieved from https://www .unodc.org/ji/

Southern African Development Community (2008). SADC Protocol on Gender and Development. Johannesburg: SADC. Retrieved from https://www.sadc.int/files/8713 15292/8364/Protocol_on_Gender_and_Development_2008.pdf

Strengthening Judicial Integrity, J. G. (2002). The Bangalore Principles of Judicial Conduct. The Hague. Retrieved from http://www.unodc.org/pdf/crime/corruption/judicial_grou p/Bangalore_principles.pdf

Sustainable Development Solutions Network. (2020). Launching a data revolution for the Sustainable Development Goals. Retrieved from https://indicators.report/targets $\mid 5-5 /$.

The Government of the Republic of Zambia. (1996). Constitution of Zambia Act 18 of 1996.

Thornton, M. (1985). Affirmative Action, Merit and the Liberal State. Australian Journal of Law and Society, 2(2), 28-39.

Thornton, M. (2007). "Otherness" on the Bench: How Merit is Gendered. Sydney Law Review, 29, 391-413.

Vial, A.C., Napier, J.L., \& Brescoll, V.L. (2016). A Bed of Thorns: Female Leaders and the Self-Reinforcing Cycle of Illegitimacy. The Leadership Quarterly, 27(3), 400-414. https://doi.org/10.1016/j.leaqua.2015.12.004 


\section{Tabeth Masengu}

Vos de, P. (2013). The JSC Must Redefine Merit to Advance Judicial Transformation. Constitutionally Speaking. Retrieved May 8, 2018, from https://constitutionallyspeaking .co.za/the-jsc-must-redefine-merit-to-advance-judicial-transformation/

W, R (2018). Have the Women Failed US? A Verdict on Zambian Women in Leadership. Retrieved May 28, 2018, from https://www.zambianobserver.com/have-the-women-fai led-us-a-verdict-on-zambian-women-in-leadership/

Zambian Judicial Service Commission (1993). JSC Criteria for Appointing Judges. Lusaka: Judicial Service Commission 